\title{
PENGARUH TINGKAT EDUKASI DAN SPESIALISASI PENDIDIKAN CEO TERHADAP PERFORMA PERUSAHAAN DI INDONESIA
}

\author{
Kevin Wiyarta Erlim \\ Rita Juliana \\ Universitas Pelita Harapan \\ Email: rita.juliana@uph.edu
}

Submitted: Jan 24, 20176; Reviewed: Jan 26, 2017; Accepted: Mar 4, 2017

\begin{abstract}
Using sample of non financial Indonesia public licted firms over the period from 2005-2014, we analyze the impact of CEO education level education specialization on firm performance. Globalization has a lot of impact on professionals' careers and thus it will affect the qualification that a CEO needed. We believe that education level and CEO education specialization will affect the managerial decision making process and their strategy. This study is using panel data with fixed effect model methodology. We also did classic assumption test such as autocorrelation test, heteroscedasticity test and cross-sectional dependence test. Our analysis results that CEO education level does have impact on firm performance, and should be considered as an important aspect of a CEO.
\end{abstract}

Keywords: CEO Education Level; CEO Education Specialization; Fixed Effect Model; Firm Performance; Tobins $Q$

\section{PENDAHULUAN}

Seiring dengan berkembangnya era globalisasi, tingkat edukasi menjadi salah satu faktor penting yang perlu diperhatikan. Untuk bisa bekerja di perusahaan ternama pada saat ini, diperlukan kualifikasi tingkat edukasi dan kualitas universitas yang baik. Pada tahun 2014, kebanyakan setiap CEO pada perusahaan di Indonesia setidaknya memiliki sarjana undergraduate dan master, sedangkan jumlah CEO dengan sarjana phd masih jarang di Indonesia.

Nilai perusahaan ditetapkan melalui kinerja manajemen dan kinerja keuangan perusahaan. Kinerja keuangan dapat diukur dengan beberapa pendekatan rasio keuangan, baik likuiditas, profitabilitas, solvabilitas, aktivitas maupun rasio pasar. Kebijakan dan keputusan para investor dalam menginvestasikan modelnya ke dalam perusahaan lebih dipengaruhi oleh rasio profitabilitas yang dimiliki oleh suatu perusahaan dibandingkan dengan rasio lainnya. Hal ini dikarenakan investor menganggap bahwa rasio profitabilitas dapat memberikan gambaran tentang tingkat pengembalian atau keuntungan yang akan diterima oleh investor dari investasinya (Yadnyana, 2011).

Dalam dua dekade terakhir, pemilihan CEO (Chief Executive Officer) dalam suatu perusahaan merupakan salah satu faktor utama yang diperdebatkan oleh pemegang saham. Seiring dengan perkembangan era globalisasi, peran dari CEO menjadi semakin penting dan memiliki pengaruh yang besar dalam performa suatu perusahaan. Hal ini dikarenakan CEO menentukan strategi yang digunakan oleh suatu perusahaan (Crumley, 2008). Bagaimana CEO bisa memberikan pengaruh yang besar terhadap performa perusahaan ditentukan oleh karakteristik dari CEO sendiri, dimana karakteristik dari CEO menjelaskan bagaimana perbedaan performa suatu perusahaan dengan perusahaan yang lainnya (Bertrand \& Schoar, 2003). 
Menurut Benmelech \& Frydman (2015), karakteristik personal CEO seperti IQ (Intelligent Quotient) mempengaruhi pencapaian tingkat edukasi yang membentuk kemampuan decision-making dari CEO dan performa perusahaan. IQ mendeterminasikan kemampuan bersosial dan perekonomian seseorang, serta individu dengan intelijen yang lebih memiliki tingkat kesabaran yang tinggi dan tidak mudah panik (King, Srivastav, \& Williams, 2016). Menurut Bhagat, Bolton, \& Subramanian (2010), kemampuan CEO bisa diobservasi dan diukur dari beberapa karakteristik seperti tingkat pendidikan dan pengalaman kerja, serta karakteristik yang tidak bisa diboservasi dan diukur seperti leadership dan team-building skills. Pasar saham memiliki reaksi yang positif dan menciptakan abnormal return yang signifikan ketika CEO dengan latar belakang pendidikan yang tinggi diangkat di suatu perusahaan. Latar belakang pendidikan menggambarkan kemampuan managerial yang dierlukan untuk memberikan perfoma yang lebih superior dalam bisnis yang besar dan kompleks.

Pertumbuhan dalam bisnis institusi pendidikan juga mendorong peningkatan suatu demand terhadap General Managerial Skills dibandingkan Technical Skills. Perubahan ini disebabkan oleh fakta bahwa sebuah perusahaan saat ini menjadi semakin besar dan kompleks karena perkembangan teknologi dan inovasi didalam praktisi bisnis (Frydman, 2005). Sebagai pendukung, Bertrand \& Schoar (2003) menjelaskan bahwa CEO dengan gelar master cenderung menggunakan strategi yang lebih agresif dan lebih berspekulasi di pasar saham sehingga menghasilkan return yang lebih.

Secara fungsional, spesifikasi background memilki kontribusi terhadap pengetahuan seseorang, karena seorang manajer mendapatkan pengetahuan dan mengasah kemampuan mereka dari pengalaman yang didapat. Beberapa penelitian mengindikasikan bahwa lingkungan fungsional seorang manajer sebelum ia menempati posisi manajemen memiliki dampak terhadap cara ia berpikir, bertindak, dan mengambil keputusan (Waller, Huber, \& Glick, 1995). Palmer \& Barber (2015) melakukan penelitian dan menemukan bahwa manajer dengan background dalam fungsi administratif, seperti keuangan dan akuntansi lebih mengasosiasikan diri mereka dengan aktivitas diversifikasi dan akuisisi. Sehingga manajer dengan background tersebut akan lebih cepat beradaptasi dengan perusahaan yang tingkat 178 diversifikasinya tinggi. Manajer dengan background dalam fungsi operasional dan pemasaran secara bertolakbelakang akan lebih cepat beradaptasi dengan perusahaan yang tingkat diversifikasinya rendah, karena perusahaan tersebut membutuhkan campur tangan dari top manajemen untuk kegiatan operasionalnya agar bisa menghasilkan produk dan proses yang sinergi.

Pada penelitian ini, performa suatu perusahaan bisa dilihat berdasarkan profitabilitasnya, yang didefinisikan sebagai Tobin's $Q$. Tobin's $Q$ digunakan untuk mengukur performa perusahaan dengan membandingkan market value of equity (MVE) ditambahkan dengan book value of debt (BVD) dan dibagi dengan total aset (Rajput \& Joshi, 2014).

Pada saat ini tingkat pendidikan Indonesia semakin berkembang, jumlah lulusan SMA/sederajat berkembang pesat selama 10 tahun terakhir. Sedangkan jumlah orang yang tidak bersekolah dan tidak tamat SD semakin berkurang. Gambar 1.1 menjelaskan grafik perkembangan pendidikan di Indonesia dari tahun 1994 hingga 2015.

Gambar 1 Tingkat Pendidikan di Indonesia

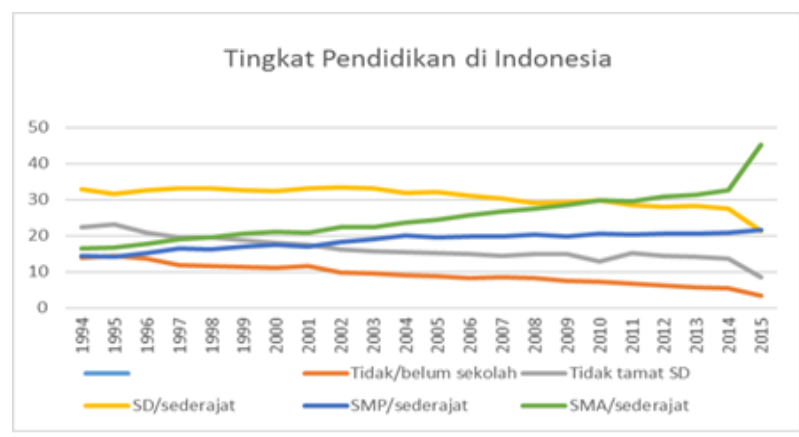

Sumber: BPS-RI, Susenas 1994-2015

Melihat semakin berkembangnya pendidikan di Indonesia, peneliti tertarik untuk melakukan penelitian tentang "Pengaruh tingkat edukasi dan spesialisasi pendidikan CEO terhadap performa perusahaan di Indonesia". Peneliti ingin mengetahui apakah dengan semakin tingginya tingkat edukasi CEO maka akan dapat memberikan performa yang lebih baik bagi perusahaan. Penelitian ini mengambil asumsi bahwa latar belakang pendidikan CEO berperan penting dalam decision making dan mencerminkan performa suatu perusahaan. Tingkat edukasi CEO mempengaruhi kemampuan decision making dan strategi yang diambil untuk suatu perusahaan. Spesialisasi 
pendidikan CEO mempengaruhi proses pembentukan pola pikir dan cara kerja seorang CEO. Oleh karena itu penelitian ini ingin membuktikan bahwa tingkat edukasi dan spesialisasi pendidikan CEO berpengaruh performa perusahaan yang terdaftar di Bursa Efek Indonesia. Dengan dilakukannya penelitian ini, peneliti berharap bisa membuktikan bahwa terdapat pengaruh tingkat edukasi dan spesialisasi pendidikan terhadap performa perusahaan sehingga dapat memberikan motivasi bagi masyarakat Indonesia untuk menjunjung pendidikan setinggi mungkin.

\section{TELAAH LITERATUR \\ Tingkat Edukasi CEO (Chief Executive Officer)}

Menurut Bhagat et al (2010), latar belakang pendidikan mempengaruhi kemampuan CEO dalam 3 hal. Pertama, edukasi memiliki potensi untuk berkontribusi terhadap pengetahuan, perspektif, dan kemampuan untuk memahami konsep technical dan teknik abstrak. Kedua, semakin tinggi edukasi dapat menjadi gambaran intelijen dan kemampuan CEO dalam menghadapi aktivitas intelektual yang menantang. Ketiga, koneksi yang didapat pada perkuliahan dapat berguna secara profesional di kedepannya

Menurut King, Srivastav, \& Williams (2016), tingkat edukasi CEO bisa dinilai dari 2 indikator, yaitu jenjang pendidikan dan kualitas pendidikan. Jenjang pendidikan dilihat dari seberapa tinggi pencapaian seorang CEO (Undergraduate, Master, PhD). Jenjang pendidikan Undergraduate memberikan pelatihan dasar bagi CEO untuk membantu mengembangkan skills yang ia miliki. Jenjang pendidikan Master merepresentasikan suatu tingkat manajemen dan pengetahuan yang didapat dari program Master. Jenjang pendidikan $P h D$ menunjukkan tingkat keahlian teknikal yang didapat dari gelar doktor. Kualitas pendidikan dilihat dari peringkat institusi pendidikan CEO tersebut, sebagai contoh CEO yang lulus dengan gelar Master dari top-20 institusi pendidikan di Amerika Serikat memberikan performa yang lebih superior dibandingkan CEO yang lulus dengan gelar Master dari institusi pendidikan yang tidak termasuk dalam top-20 di Amerika Serikat.

\section{Spesialisasi pendidikan CEO}

Menurut Wulf \& Stubner (2013), spesialisasi pendidikan CEO dibagi menjadi dua, yaitu natural sciences seperti teknik dan social sciences seperti hukum, bisnis, dan kemanusiaan. Manajer dengan background natural sciences cenderung lebih melibatkan diri mereka terhadap kegiatan operasional suatu perusahaan dan lebih terikat dengan inti bisnis mereka. Manajer dengan background social sciences cenderung lebih melihat gambaran besar dan menggunakan struktur organisasi yang lebih kompleks. CEO dengan background natural sciences memiliki proses pembelajaran yang lebih cepat di perusahaan yang tingkat diversifikasinya rendah dan mereka lebih mampu beradaptasi dengan tantangan yang dimana membutuhkan campur tangan kuat dari manajemen dalam proses operasionalnya untuk menciptakan kesinergian antara produk dan proses operasionalnya. Secara kebalikannya, CEO dengan background social sciences lebih mampu beradaptasi di perusahaan dengan tingkat diversifikasi yang tinggi karena lebih berurusan dengan keputusan strategis perusahaan.

\section{Performa Perusahaan}

Salah satu cara untuk mengetahui performa Perusahaan adalah dengan cara mengukur Tobin's $Q$. Tobin's $Q$ digunakan untuk mengukur performa perusahaan dengan membandingkan market value of equity (MVE) ditambahkan dengan book value of debt (BVD) dan dibagi dengan total aset. Tobin's Q digunakan merupakan indikasi untuk melihat growth opportunities sebuah perusahaan. Menurut Tobin (1969), perusahaan dengan nilai Tobin's Q yang tinggi berarti mampu menggunakan sumberdayanya secara efektif, sebaliknya perusahaan dengan nilai Tobin's Q yang rendah berarti tidak mampu menggunakan sumberdayanya secara efektif.

\section{Hubungan antara Tingkat Edukasi CEO dengan Performa Perusahaan}

CEO merupakan seorang individu yang memiliki pengaruh yang paling besar dalam performa perusahaan. CEO dengan latar belakang pendidikan S3 memberikan performa yang lebih baik pada suatu perusahaan. Namun bukan berarti CEO latar belakang pendidikan S1 dan S2 memberikan performa yang buruk. Melainkan CEO dengan latar pendidikan S1 dan S2 memberikan performa yang baik, namun CEO dengan latar belakang pendidikan S3 memberikan performa yang lebih baik. CEO dengan latar belakang pendidikan S3 cenderung memberikan performa yang lebih baik karena 
memiliki tingkat intensitas mengambil resiko yang tinggi (King et al., 2016).

CEO dengan latar belakang pendidikan yang tinggi lebih bisa memproses informasi dengan cepat dan menerima perubahan yang signifikan dalam sebuah perusahaan (Bantel \& Jackson, 1989). CFO (Chief Financial Officer) yang memiliki latar pendidikan $\mathrm{PhD}$ lebih mengikuti masukan akademis dan menggunakan cara present value dalam mengevaluasi projek baru (Graham \& Harvey, 2002).

\section{Hubungan Antara Spesialisasi Pendidikan CEO dengan Performa Perusahaan}

CEO yang memiliki latar belakang pendidikan yang sinergi dengan industri perusahaan cenderung menghasilkan performa yang lebih baik dibandingkan dengan CEO yang tidak memiliki kesinergian antara latar belakang pendidikan dengan industri perusahaan. Wulf \& Stubner (2013) membagi spesialisasi pendidikan CEO menjadi natural sciences dan social sciences dan berpendapat bahwa kesinergian antara latar belakang pendidikan dengan industri perusahaan akan menghasilkan strategi yang lebih sesuai sehinga menghasilkan performa yang lebih baik.

\section{Penelitian Sebelumnya}

Bhagat et al (2010) melakukan penelitian untuk menganalisa hubungan edukasi CEO, CEO turn over, dan performa perusahaan. Penelitian ini menggunakan data lebih dari 2600 kasus tentang CEO turnover dari tahun 1993 hingga 2007. Hasil dari penelitian ini menunjukkan bahwa edukasi CEO tidak memiliki peran yang besar dalam kebijakan perusahaan untuk mengganti CEO, melainkan CEO yang memberikan performa buruk akan diganti tanpa memandang edukasinya. Namun edukasi CEO memiliki peran yang signifikan dalam pemilihan CEO pengganti. Penelitian ini tidak menemukan hubungan yang signifikan antar edukasi CEO dengan performa perusahaan. Hasil penelitian ini mengarahkan ke implikasi yang membingungkan, dimana edukasi CEO memiliki peran yang penting dalam memilih CEO namun memberikan pengaruh negatif pada performa perusahaan.

Darmadi (2011) melakukan penelitian untuk menguji pengaruh tingkat edukasi CEO dan board member terhadap performa perusahaan. Penelitian ini menggunakan 4 variabel untuk menggambarkan tingkat edukasi CEO, yaitu gelar postgraduate, gelar yang didapat dari universitas domestik yang ternama, 180 gelar yang didapat dari negara maju, dan gelar financial disciplines. Pengukuran kinerja perushaan dalam penelitian ini adalah ROA dan Tobin's Q. Hasil penelitian ini menemukan bahwa pada anggota BOC gelar postgraduate dan gelar dari universitas ternama memiliki dampak yang signifikan terhadap ROA. Namun anggota BOC yang memiliki gelar dari negara maju memiliki dampak negatif terhadap pengukuran profitabilitas. Dengan menggunakan metode Tobin's Q, gelar postgraduate yang dimiliki anggota BOM termasuk CEO memberikan pengaruh yang signifikan dan positif. Sedangkan gelar financial discipline memberikan pengaruh yang negatif dan tidak signifikan. Pada akhirnya, perusahaan yang dikepalai oleh CEO dengan gelar dari universitas ternama memberikan tingkat profitabilitas yang lebih tinggi. Penelitian ini menguji pengaruh tingkat edukai CEO dan board member terhadap perusahaan yang terdaftar di Bursa Efek Indonesia, namun penelitian ini memiliki kelemahan yaitu observasi yang digunakan hanya 160 observasi.

Miller, Xu, \& Mehrotra (2015) meneliti dengan spesifik kondisi dimana tingkat edukasi CEO dinilai sebagai suatu human capital berpotensi yang bisa menghasilkan performa yang menguntungkan. Berdasarkan recoursebased view perusahaan, hanya faktor yang relatif langka dapat membantu perusahan mencapai performa yang superior, dan juga hanya faktor yang susah di imitasi akan mendukung performa superior yang sustainable. Miller et al (2015) berpendapat bahwa tingkat edukasi CEO dari institusi pendidikan yang elit adalah sesuatu yang langka dan susah untuk diimitasi, dan memiliki potensi yang lebih besar untuk memberikan kontribusi performa yang superior. Peneliti membuat konsep bahwa CEO yang berasal dari institusi pendidikan yang elit memiliki talenta yang superior karena dengan diterimanya ke institusi pendidikan yang elit menggambarkan bakat dan motivasi CEO tersebut, dan juga edukasi yang diberikan akan menyempurnakan bakat CEO yang diterima ke dalam institusi pendidikan tersebut. Oleh karena itu dapat dikatakan bahwa CEO yang lulus dari institusi pendidikan yang elit akan memiliki keunggulan dalam human capital.. Hasil penelitian ini menghasilkan suatu argumen dimana tingkat edukasi CEO memiliki pengaruh paling besar dalam strategi yang diambil perusahaan ketika beroperasi dan berdampak ke peforma perusahaan. 
Amornkitvikai (2015) melakukan penelitian untuk menguji pentingnya inovasi teknologi dan karakteristik CEO terhadap cost efficiency industri manufaktur di Thailand. Karakteristik CEO yang digunakan dalam penelitian ini adalah latar belakang pendidikan, gender, pengalaman, dan kebangsaan. Faktor variabel lain yang digunakan dalam penelitian ini adalah unskilled foreign labour, firm size, umur perusahaan, dan kepemilikian domestik terhadap cost efficiency. Hasil dari penelitian ini menyimpulkan bahwa inovasi teknologi memiliki peran penting dalam meningkatkan cost efficiency industri manufaktur di Thailand. Karakteristik CEO seperti latar belakang pendidikan dapat memberikan pengaruh terhadap cost efficiency secara signifikan, sedangkan karakteristik lain seperti gender, pengalaman, dan kebangsaan tidak memberikan pengaruh yang signifikan terhadap cost efficiency.

King et al (2016) melakukan penelitian untuk menguji bagaimana tingkat edukasi CEO mempengaruhi performa bank. Penelitian ini mendefinisikan tingkat edukasi CEO berdasarkan tingkat pendidikan (Undergraduate, Master, $P h D)$ dan kualitas pendidikan (peringkat universitas CEO). Performa bank diukur dengan menggunakan ROA (Return on Asset). Hasil dari penelitian ini menjelaskan bahwa CEO dengan latar belakang pendidikan yang tinggi menghasilkan performa bank dan tingkat profitabilitas yang lebih tinggi. CEO dengan latar belakang pendidikan yang tinggi mengikuti business model yang lebih beresiko dan inovatif sehingga menghasilkan performa bank yang superior.

\section{Pengembangan Hipotesis}

Tingkat Edukasi CEO dan Performa Perusahaan Berbagai macam penelitian tentang pengaruh tingkat edukasi CEO terhadap performa perusahaan telah dilakukan sebagaimana disebutkan di atas. CEO merupakan orang yang memiliki pengaruh paling besar di sebuah perusahaan (Miller et al, 2015). Keputusan akan strategi yang akan diambil oleh sebuah perusahaan, struktur perusahaan, dan proses operasional ditentukan oleh CEO. IQ memiliki pengaruh terhadap kemampuan decision making CEO dan kemampuan CEO menyelesaikan jenjang pendidikan (Amornkitvikai, 2015).

Melihat berbagai penelitian sebelumnya oleh (Amornkitvikai, 2015) (Darmadi, 2011) (King et al., 2016) menyimpulkan bahwa tingkat edukasi CEO memiliki pengaruh positif terhadap performa perusahaan di negara maju. Namun ada penelitian yang dilakukan oleh (Bhagat et al., 2010) yang menyimpulkan bahwa latar belakang pendidikan berpengaruh negatif terhadap performa perusahaan. Oleh karena terdapat dua hasil penelitian yang kontradiksi, peneliti ingin menguji pengaruh tingkat edukasi CEO terhadap performa perusahaan di negara berkembang seperti Indonesia. Untuk itu penelitian ini merumuskan hipotesis $\mathrm{H} 1$ sebagai berikut,

H1: Tingkat edukasi CEO berpengaruh terhadap Performa Perusahaan.

Pengaruh Spesialisasi Pendidikan CEO Terhadap Performa Perusahaan.

Menurut Wulf \& Stubner (2013), spesialisasi pendidikan dibagi menjadi natural science dan social science. Dimana CEO dengan background natural science cenderung lebih unggul di bidang operasional dan CEO dengan background social science cenderung lebih unggul dalam menentukan strategi perusahaan. Latar belakang pendidikan yang sinergi terhadap industri perusahaan akan menghasilkan performa yang lebih baik, namun hasil penelitian tersebut menyimpulkan bahwa spesialisasi pendidikan CEO tidak memiliki pengaruh terhadap performa perusahaan di Jerman. Peneliti ingin menguji apakah spesialisasi pendidikan CEO berpengaruh terhadap performa perusahaan di negara berkembang seperti Indonesia. Untuk itu penelitian ini merumuskan hipotesis $\mathrm{H} 2$ sebagai berikut,

$\mathrm{H}$ 2: Spesialisasi pendidikan CEO berpengaruh terhadap Performa Perusahaan.

\section{METODE PENELITIAN Sampel Penelitian}

Sampel penelitian ini adalah perusahaan yang terdaftar dalam Bursa Efek Indonesia yang menerbitkan laporan tahunan dari tahun 2005 hingga 2014. Penelitian ini menggunakan periode 10 tahun dengan tahun yang relatif baru agar diharapkan dapat memberikan hasil yang relevan. Penelitian ini seharusnya menggunakan data hingga tahun 2015 namun karena masih belum lengkapnya data periode tahun 2015, maka data yang paling baru pada masa penelitian ini adalah tahun 2014. Total perusahaan yang sesuai dengan kriteria dan digunakan sebagai sampel berjumlah 138 perusahaan.

Metode pengumpulan data yang dilakukan yaitu perolehan data sekunder atau tidak langsung yang dikumpulkan dari sumber-sumber yang sudah ada. Dalam penelitian ini, data berupa laporan tahunan perusahaan yang 
terdaftar di BEI pada periode 2005-2014. Data tersebut dapat diperoleh dari website IDX (Indonesia Stock exchange).

Dalam penelitian ini perusahaan yang menjadi sampel adalah perusahaan yang dipilih berdasaran metode purposive sampling yang termasuk Non Probability Sampling dengan tujuan untuk mendapatkan sampel yang sesuai dengan kriteria yang ditentukan. Adapun kriteria sampel yang digunakan sebagai berikut:

1. Penelitian ini menggunakan data dari perusahaan yang sudah go public di Bursa Efek Indonesia sebelum tahun 2005.

2. Perusahaan yang mempublikasi laporan keuangan dan laporan tahunan pada tahun 2005-2014

3. Perusahaan yang mengungkapkan informasi mengenai profil anggota dewan dalam laporan tahunan.

4. Perusahaan yang memiliki data lengkap lainnya yang terkait dengan variabel yang digunakan dalam penelitian yaitu informasi keuangan terkait variabel dependen dan variabel kontrol penelitian.

Tabel 1. Proses Seleksi Perusahaan

\begin{tabular}{|c|c|}
\hline $\begin{array}{l}\text { Total Perusahaan di BEI pada bulan } \\
\text { Juli } 2016 .\end{array}$ & 526 \\
\hline $\begin{array}{l}\text { Perusahaan yang melakukan IPO } \\
\text { diatas bulan Desember 2004 dan } \\
\text { berasal dari industri Finance atau } \\
\text { Banking. }\end{array}$ & (291) \\
\hline $\begin{array}{l}\text { Perusahaan yang tidak memiliki data } \\
\text { laporan keuangan yang lengkap }\end{array}$ & (97) \\
\hline $\begin{array}{l}\text { Total Perusahaan yang digunakan } \\
\text { pada penelitian }\end{array}$ & $\underline{138}$ \\
\hline
\end{tabular}

Dengan demikian, total perusahaan yang sesuai dengan kriteria dan digunakan sebagai sampel berjumlah 138 perusahaan.

\section{Model Penelitian}

Model yang digunakan dalam pengujian hipotesis penelitian ini adalah sebagai berikut:

FRMC $=\sigma+\beta_{1} \mathrm{UG}+\beta_{2}$ MSTR $+\beta_{3}$ PHD $+\beta_{4}$ QUAL $+\beta_{5}$ SPEC $+\beta_{6}$ AGE $+\beta_{7}$ SIZE $+\beta_{8} \mathrm{LEV}+\beta_{9}$ GROWTH $+\beta_{10} \mathrm{CR}+\varepsilon$

Keterangan:

$\mathrm{FRMC}=$ Performa perusahaan yang diukur dengan menggunakan variabel Tobin's Q.

$\mathrm{UG}=$ Tingkat Edukasi CEO (Undergraduate)
MSTR $=$ Tingkat Edukasi CEO (Master $)$

$\mathrm{PHD}=$ Tingkat Edukasi CEO $(P h D)$

QUAL $=$ Kualitas Universitas

SPEC $=$ Spesialisasi Pendidikan

$\mathrm{AGE}=$ Usia Perusahaan

SIZE $=$ natural logarithm total asset

$\mathrm{LEV}=$ Leverage (Debt-Asset Ratio)

GROWTH $=$ pertumbuhan penjualan

$\mathrm{CR}=$ Current Ratio

$\varepsilon^{\prime}=\quad$ Error term, residual

Operasionalisasi Variabel Penelitian

Seluruh variabel dependen, independen dan control di ambil dan di hitung dengan menggunakan data yang tersedia di laporan keuangan dan laporan tahunan perusahaan sampel.

\section{Variabel Independen}

Variabel independen atau variabel bebas adalah variabel yang mempengaruhi atau menjadi sebab perubahannya variabel dependen (Hill, Griffiths, Lim, \& Lim, 2011). Variabel ini biasa disimbolkan dengan $(\mathrm{X})$, variabel independen dalam penelitian ini adalah tingkat edukasi CEO yaitu undergraduate, master, phd, kualitas universitas, dan spesialisasi pendidikan. Kami melihat informasi pendidikan CEO yang tersedia di laporan tahunan perusahaan sampel.

1. Variabel tingkat edukasi CEO dalam penelitian ini dibagi menjadi undergraduate, master, dan $P h D$. Variabel ini ditandakan dengan 1=tingkat edukasi akhir CEO dan $0=$ bukan tingkat edukasi akhir CEO.

2. Variabel kualitas universitas dalam penelitian ini ditandakan dengan $1=$ peringkat universitas yang ditempuh CEO berada dalam 9 besar universitas terbaik di Indonesia atau universitas luar negeri yang memiliki peringkat lebih baik daripada Universitas Indonesia dan $0=$ peringkat universitas yang ditempuh CEO tidak berada dalam 9 besar universitas terbaik di Indonesia atau universitas luar negeri yang memiliki peringkat diatas Universitas Indonesia.

3. Variabel spesialisasi pendidikan dalam penelitian ini ditandakan dengan $1=$ jurusan yang diambil oleh CEO sesuai dengan industri tempat dia bekerja dan $0=$ jurusan yang diambil oleh CEO tidak sesuai dengan industri tempat dia bekerja. 
Tobin's $Q=\frac{\text { Market Value Equity }+ \text { Book Value Debt }}{\text { Total Asset }}$

\section{Variabel Kendali}

Variabel kendali (control variable) adalah variabel yang dikendalikan atau dibuat konstan sehingga pengaruh variabel independen terhadap dependen tidak dipengaruhi oleh faktor luar yang tidak dapat diteliti (Hill et al., 2011). Variabel kontrol dalam penelitian ini usia perusahaan, current ratio, size perusahaan, leverage, dan pertumbuhan penjualan perusahaan. Hasil penelitian Khatab, Masood, Zaman, Saleem, \& Saeed (2010) menemukan bahwa variabel size perusahaan, leverage, dan pertumbuhan penjualan memiliki pengaruh terhadap Tobin's Q. Penggunaan usia perusahaan sebagai variabel kendali terhadap performa perusahaan dalam penelitian ini didukung oleh penelitian Noordin \& Mohtar (2014). Sedangkan penggunaan Current Ratio sebagai variabel kendali terhadap performa perusahaan dalam penelitian ini didukung oleh peneltian Garanina \& Petrova (2015).

\section{Usia Perusahaan}

Usia perusahaan dalam penelitian ini diukur dari pertama kali perusahaan tersebut didirikan.

\section{Current Ratio}

Current Ratio menunjukkan kemampuan aktiva lancar untuk membayar hutang lancar. Semakin besar Current Ratio menunjukkan semakin tinggi kemampuan perusahaan dalam memenuhi kewajiban jangka pendeknya.

$$
\text { Current Ratio }=\frac{\text { Curent Asset }}{\text { Current Liabilities }}
$$

3. Size Perusahaan

Size perusahaan memiliki pengaruh terhadap seberapa banyak uang yang dapat dihasilkan oleh suatu perusahaan. Penelitian ini mendefinisikan size perusahaan dengan menggunakan perhitungan sebagai berikut,

$$
\text { Firm Size }=\ln \text { Total Asset }
$$

\section{Leverage}

Leverage suatu perusahaan menunjukkan besarnya total hutang perusahaan terhadap total aset yang dimiliki perusahaan.

$$
\text { Leverage }=\frac{\text { Total Liabilities }}{\text { Total Asset }}
$$

5. Pertumbuhan Penjualan Perusahaan Pertumbuhan pejualan perusahaan digunakan untuk mengukur tingkat pertumbuhan penjualan suatu perusahaan. Tingkat pertumbuhan penjualan perusahaan didefinisikan sebagai berikut,

$$
\text { Sales Growth }=\frac{\text { Net } \text { sale }_{\mathrm{t}}-\text { Net }_{\text {sales }} \mathrm{s}_{\mathrm{t}-1}}{\text { Net }_{\text {sale }} \mathrm{s}_{\mathrm{t}-1}}
$$

Dalam menganalisis data penelitian dan menguji hipotesis penelitian yaitu dengan menggunakan statistik deskriptif dan uji regresi. Sedangkan alat yang digunakan dalam mengolah data yaitu aplikasi stata. Penelitian ini menggunakan data tahunan perusahaan sehinga data ini diklasifikasikan sebagai data panel. Data panel adalah kombinasi dari cross-section dan time series data, selain itu juga data panel dikenal sebagai longitudinal/ cross-sectional time series data. Sebuah kumpulan entitas data yang diobservasi dari waktu ke waktu (TorresReyna, 2007)

\section{ANALISIS DAN PEMBAHASAN HASIL Statistik Des kriptif}

Statistik Deskriptif dapat digunakan untuk memberikan gambaran pada nilai mean dan standar deviasi data. Statistik Deskriptif juga menunjukkan nilai minimum dan maximum tiap variable untuk memastikan bahwa setiap error yang ditemukan dapat dikurangi. Berikut ini adalah karakteristik dari data penelitian:

Tabel 2 Variabel Statistik Deskriptif

\begin{tabular}{lllll}
\hline \multicolumn{1}{c}{ VARLABLES } & MEAN & STD.DEV. & MIN. & MAX. \\
\hline $\begin{array}{l}\text { Undergraduate } \\
\text { Dummy }\end{array}$ & 0.650725 & 0.476914 & 0 & 1 \\
Master Dummy & 0.297826 & 0.457468 & 0 & 1 \\
& & & & 1 \\
PhD Dummy & 0.037681 & 0.190493 & 0 & 1 \\
Quality Dummy & 0.653623 & 0.475988 & 0 & 1 \\
Specialization & 0.586957 & 0.492559 & 0 & 1 \\
Dummy & & & & \\
AGE & 32.58696 & 21.61457 & 2 & 158 \\
TobinsQ & 1.189807 & 0.685032 & 0.4565 & 2.68 \\
Current Ratio & 2.225218 & 1.600401 & 0.6964 & 5.7741 \\
Sales Growth & 0.146354 & 0.248289 & -0.2184 & 0.6245 \\
$\begin{array}{l}\text { Leverage } \\
\text { Size }\end{array}$ & 0.478103 & 0.217576 & 0.1488 & 0.818 \\
\hline & 27.71573 & 1.520518 & 25.4462 & 30.0781 \\
\hline & & & &
\end{tabular}

Sumber: Hasil pengolahan data dengan Stata.

Tabel 2 menunjukkan hasil statistik deskriptif dari semua 138 perusahaan sampel 
yang digunakan dalam penelitian ini dengan total 1380 observasi. Secara general, observasi dengan jumlah sampel yang besar akan bisa menyebabkan terjadinya outlier. Outlier sendiri merupakan nilai ekstrim yang bisa mempengaruhi estimasi regresi koefisien yang salah. Untuk mengatasi masalah ini, maka dilakukan strategi winsorization. Hellerstein (2008) menjelaskan bahwa winsorization adalah suatu teknik untuk mengurangi efek dari outlier dalam sampel dengan merubah nilai ekstrim dalam sample menjadi nilai yang wajar.

Pada tabel 2 dapat dilihat variable dummy Undergraduate, Master, dan PhD memiliki nilai minimum 0 dan maksimum 1 yang menjelaskan tingkat edukasi terakhir Chief Executive Officer. Dengan nilai rata-rata Undergraduate 0,6507, Master 0,2978, dan $P h D$ 0,0376 menjelaskan bahwa sebanyak 65,07\% Chief Executive Officer dalam penelitian ini memiliki pendidikan akhir Undergraduate, $29,78 \%$ memiliki pendidikan akhir Master, dan 3,76\% memiliki pendidikan $P h D$. Namun jumlah kumulasi persentase hanya $98,61 \%$, dimana menjelaskan bahwa sisa $1,39 \%$ Chief Executive Officer dalam penelitian ini hanya menempuh pendidikan hingga Sekolah Menengah Atas atau hanya mengambil pelatihan terhadap jenis industri perusahaannya.

Variabel dummy Quality memiliki nilai minimum 0 dan maksimum 1 yang menjelaskan apakah universitas yang ditempuh oleh Chief Executive Officer merupakan top 9 universitas di Indonesia atau Universitas dari luar negeri dengan peringkat yang lebih tinggi dari Universitas Indonesia. Variabel Quality memiliki nilai rata-rata 0.6536 yang menjelaskan bahwa sebanyak $65.36 \%$ Chief Executive Officer dalam penelitian ini berasal dari universitas dengan peringkat top 9 di Indonesia atau univeristas luar negeri dengan peringkat yang lebih tinggi dari Universitas Indonesia. Sedangkan variabel dummy Specialization memiliki nilai minimum 0 dan maksimum 1 yang menjelaskan apakah jurusan yang diambil oleh Chief Executive Officer sesuai dengan industri perusahaannya. Variabel Specialization memiliki nilai rata-rata 0.5869 yang menjelaskan bahwa sebanyak $58.69 \%$ Chief Executive Officer dalam penelitian ini menjalankan perusahaan dengan industri yang sesuai dengan latar belakang pendidikannya. Variabel dummy Age memiliki nilai minimum 2 dan maksimum 152 yang menjelaskan umur perusahaan dari pertama kali didirikan dalam penelitian ini paling muda berusia 2 tahun hingga paling tua 152 tahun. Variabel Age memiliki nilai 184 rata-rata 32.5689 yang menjelaskan bahwa ratarata usia perusahaan dalam penelitian ini adalah 32.5689 tahun.

Berikutnya Variabel Current Ratio perusahaan sampel memiliki nilai rata 2.2252 dengan nilai minimum 0.6964 dan maksimum 5.7741. Leverage perusahaan sampel memiliki nilai rata-rata 0.4781 dengan nilai minimum 0.1488 dan maksimum 0.818. Sales Growth perusahaan sampel memiliki nilai rata-rata 2.3108 dengan nilai minimum -1 dan maksimum 1.7011. Size perusahaan sampel memiliki nilai rata-rata 27.7157 dengan nilai minimum 25.4462 dan maksimum 30.0781.

Selain itu, $R$-squared hasil regresi ini bernilai $19.86 \%$, nilai tersebut diperoleh karena ada banyak variabel lain yang mempengaruhi variabel dependen. Sedangkan hanya variabel usia perusahaan, Current Ratio, Sales Growth, Leverage, dan Size perusahaan yang dipakai dalam penelitian ini.

\section{Hasil Regresi dan Diskusi}

Tabel 3 menunjukkan hasil regresi panel data fixed effect model untuk menguji hipotesis apakah pendidikan CEO memiliki pengaruh terhadap performa perusahaan atau tidak. Uji hipotesis yang digunakan adalah dengan melihat hasil signifikansi koefisien dengan level signifikansi $10 \%, 5 \%$ dan $1 \%$.

Tabel 3. Driscoll and Kraay Standards Errors

\begin{tabular}{ll}
\hline & Tobin's $Q$ \\
\hline Undergraduate & $0.6380648^{* * *}$ \\
& 4.12 \\
Master & $0.615404^{* * *}$ \\
& 3.61 \\
PhD & $0.4613503^{* * *}$ \\
& 3.2 \\
Quality & $0.0876492^{* * *}$ \\
& 3.28 \\
Specialization & -0.0161175 \\
& -0.5 \\
Age & $0.0491899^{* * *}$ \\
& 8.86 \\
Current Ratio & $0.0150681^{*}$ \\
& 1.86 \\
Sales Growth & 0.0492321 \\
& 1.44 \\
Leverage & $0.8805643^{* * *}$ \\
& 17.49 \\
Size & $-0.3593461^{* * *}$ \\
& -8.14 \\
& 8.420955 \\
cons & 7.05 \\
& $R-5 q u a r e d=0.1986$ \\
& $F(10,137)=1239.89$ \\
& Prob $=F$ \\
\hline &
\end{tabular}

Keterangan: *** signifikan pada tingkat $1 \%$; ** signifikan pada tingkat 5\%; *signifikan pada tingkat $10 \%$ 


\section{Tingkat Edukasi CEO}

Hasil dari regresi Driscoll and Kraay dijelaskan pada tabel 3 dan menjawab pertanyaan penelitian dan menerima hipotesis 1, yaitu terdapat pengaruh tingkat edukasi CEO terhadap Performa Perusahaan, dan didukung oleh hasil penelitian (Miller et al., 2015) dan (Darmadi, 2011). (Miller et al., 2015) dan (Darmadi, 2011) meneliti pengaruh tingkat edukasi CEO terhadap performa perusahaan dan mendapatkan hasil bahwa tingkat edukasi CEO berpengaruh terhadap performa perusahaan dengan menggunakan variabel dependen Tobin's $Q$. Hasil tersebut menunjukkan bahwa semakin tinggi tingkat pendidikan seorang CEO, maka akan dapat memberikan performa perusahaan yang semakin tinggi.

\section{Spesialisasi Pendidikan CEO}

Hasil dari regresi tabel 3 menjawab pertanyaan penelitian dan menolak hipotesis 2, yaitu terdapat pengaruh spesialisasi pendidikan terhadap Performa Perusahaan, dan didukung oleh hasil penelitian (Wulf \& Stubner, 2013) yang melakukan penelitian position specific knowledge seorang CEO terhadap performa perusahaan dan menyimpulkan bahwa spesialisasi pendidikan CEO tidak berpengaruh terhadap performa perusahaan. Kinerja CEO yang memiliki spesialisasi pendidikan dan yang tidak memiliki spesialisasi pendidikan dalam jenis industrinya mampu memberikan performa yang sama. Hal ini menunjukkan bahwa CEO dengan spesialisasi pendidikan sesuai dengan jenis industrinya tidak memberikan performa yang lebih signifikan dibandingkan CEO yang tidak memiliki spesialisasi pendidikan.

\section{KESIMPULAN DAN SARAN}

Penelitian ini dilakukan untuk mengetahui apakah ada pengaruh tingkat edukasi CEO dan spesialisasi pendidikan CEO terhadap performa perusahaan. Penelitian ini dilakukan dengan menggunakan sampel 138 perusahaan di Indonesia dari periode 2005 hingga 2014.

Tingkat Edukasi CEO berpengaruh positif terhadap performa perusahaan yang diukur dengan variabel dependen TobinsQ. Hasil dari penelitian ini sama dengan penelitian (Darmadi, 2011) dan (Miller et al., 2015) yang membahas tingkat edukasi CEO terhadap performa perusahaan. Tobin's Q merefleksikan evaluasi nilai suatu perusahaan oleh market yang digunakan oleh investor. Tobin's Q juga merefleksikan growth opportunities sebuah perusahaan sehingga dapat disimpulkan bahwa tingkat edukasi CEO merupakan pertimbangan investor dalam menilai prospek suatu perusahaan.

Spesialisi pendidikan CEO tidak berpengaruh terhadap performa perusahan. Hasil dari penelitan ini didukung oleh penelitian (Wulf \& Stubner, 2013) yang membahas tentang position specific knowledge seorang CEO terhadap performa perusahaan. Hasil penelitian tersebut menemukan bahwa spesialisasi pendidikan tidak berpengaruh terhadap performa perusahaan dikarenakan sesuai atau tidaknya spesialisasi pendidikan seorang CEO tetap memberikan performa yang sama.

Penelitian ini hanya menguji pengaruh pendidikan CEO perusahaan, namun melihat dalam sebuah badan direksi masih ada anggota lainnya, peneliti menyarankan untuk melakukan penelitian serupa dan menguji seluruh anggota badan direksi perusahaan dan memperpanjang periode penelitian dengan tujuan untuk mendapatkan hasil penelitian yang lebih relevan.

\section{REFERENSI}

Amornkitvikai, Y. (2015). Technological Innovation , CEO Characteristics and Firm Cost Efficiency An Application of the Stochastic Cost Frontier Model to Thai Manufacturers, 2(1), 49-68.

Bantel, K. A., \& Jackson, S. E. (1989). Top management and innovations in banking: Does the composition of the top team make a difference? Strategic Management Journal, 10(April), 107124. http://doi.org/10.1002/smj.4250100709

Benmelech, E., \& Frydman, C. (2015). Military CEO.

Bertrand, M., \& Schoar, A. (2003). MANAGING WITH STYLE: THE EFFECT OF MANAGERS ON FIRM POLICIES.

Bhagat, S., Bolton, B., \& Subramanian, A. (2010). CEO Education , CEO Turnover , and Firm Performance CEO Education, CEO Turnover, and Firm Performance.

Crumley, C. R. (2008). A Study of the Relationship between Firm Performance and CEO Compensation in the U.S. Commercial Banking Industry. Journal of Applied Management and Entrepreneurship, 13(2), 26.

Darmadi, S. (2011). Board Members 'Education 
and Firm Performance : Evidence from a Developing Economy, (2), 1-38.

Frydman, C. (2005). Rising Through the Ranks: The Evolution of the Market for Corporate Executives, 1936-2003.

Garanina, T., \& Petrova, O. (2015). Liquidity, cash conversion cycle and financial performance: Case of Russian companies. Investment Management and Financial Innovations, 12(1), 90-100.

Graham, J., \& Harvey, C. (2002). HOW DO CFOS MAKE CAPITAL BUDGETING AND CAPITAL STRUCTURE DECISIONS?

Hellerstein, J. M. (2008). Quantitative Data Cleaning for Large Databases. United Nations Economic Commission for Europe, 42.

Hill, C. R., Griffiths, W. E., Lim, G. C., \& Lim, M. A. (2011). Principle of Econometrics (4th ed.).

Khatab, H., Masood, M., Zaman, K., Saleem, S., \& Saeed, B. (2010). Corporate Governance and Firm Performance : A Case study of Karachi Stock Market. International Journal of Trade, Economics and Finance, 2(1), 39-43.

King, T., Srivastav, A., \& Williams, J. (2016). What's in an education? Implications of CEO education for bank performance. Journal of Corporate Finance, 44(April).

http://doi.org/10.1016/j.jcorpfin.2016.01. 003

Miller, D., Xu, X., \& Mehrotra, V. (2015). When is human capital a valuable resource? the performance effects of Ivy league selection among celebrated CEOs. Strategic Management Journal, 36(6), 930-944.

http://doi.org/10.1002/smj.2251

Noordin, M. A., \& Mohtar, S. (2014). Age: Does it Matter for Firms to Perform? International Journal of Academic Research in Business and Social Sciences, 4(3), 252-260. http://doi.org/10.6007/IJARBSS/v4i3/704

Palmer, D., \& Barber, B. M. (2015). Owning Families : A Social Class Theory of Corporate Aoquisitions in the 1960s. Science.

Rajput, N., \& Joshi, B. (2014). Shareholder Types, Corporate Governance and Firm Performance: An Anecdote from Indian
Corporate Sector. Asian Journal of Finance \& Accounting, 7(1), 45. http://doi.org/10.5296/ajfa.v7i1.6070

Tobin, J. (1969). A General Equilibrium Approach To Monetary Theory Author ( $\mathrm{s}$ ): James Tobin Source : Journal of Money, Credit and Banking, Vol . 1, No . 1 ( Feb ., 1969 ), pp . 15-29 Published by : Ohio State University Press Stable URL : http://www.jstor.org/stable/1, I(1), 1529.

Torres-Reyna, O. (2007). Panel Data Analysis Fixed and Random Effects using Stata (v. 4.2). Retrieved from http://dss.princeton.edu/training/

Waller, M. J., Huber, G. P., \& Glick, W. H. (1995).

FUNCTIONAL

BACKGROUND AS A
DETERMINANT OF EXECUTIVES' SELECTIVE PERCEPTION.

Wulf, T., \& Stubner, S. (2013). Position-specific knowledge, new CEO learning and firm performance. European J. of International Management, 7(1), 6. http://doi.org/10.1504/EJIM.2013.05209 7

Yadnyana, R. dan. (2011). Pengaruh Good Corporate Governance Dan, 1(2), 1-17. 